\title{
Parodie, trawestacje, uwertury - znaczenie zabiegów stylizacyjnych w szkolnych etiudach Marka Piwowskiego
}

Kolejne pokolenia zaśmiewają się z absurdalnego humoru Rejsu (1970), z pewnym osłupieniem i nie bez uśmiechu na twarzy słuchają przechwałek Czesława Niemena w Sukcesie (1968) i przyglądają się niemieckiemu hełmowi na wierzchołku sosny w filmie Pożar! Pożar! Coś nareszcie dzieje się (1967). W czterech zrealizowanych podczas studiów w łódzkiej Szkole Filmowej etiudach odnajdujemy zapowiedź owego specyficznego poczucia humoru, który urzeka, ale i bywa niewygodny, gdy jego przedmiotem stają się nasze własne przywary, nasza głupota czy lekkomyślność. W moim przekonaniu, szkolne filmy Piwowskiego zapowiadały przyszłego wielkiego parodystę polskiego kina, który w niemal wszystkich swych filmach posługuje się tą specyficzną odmianą komicznej stylizacji. Owe stylizacje, które dotyczą różnych poziomów organizacji utworów filmowych, są jednym z głównych źródeł komizmu.

I mamy nasz Rejs - pisze Marek Hendrykowski. - Ściślej - kunsztownie zawoalowaną, a przecież doskonale czytelną dla widza parodię pewnego, obowiązującego wówczas, stylu myślenia o polskim filmie, którego skutki ukazuje się à rebours. [...] Rejs okazuje się na tym tle zjawiskiem wyjątkowym, filmem niepodobnym do żadnego z tych, które wówczas w Polsce kręcono, z wyjątkiem filmów... Marka Piwowskiego. Niezmiernie istotny kontekst Rejsu, co warto osobno podkreślić, stanowi kierunek twórczych poszukiwań autora - trajektoria, po której konsekwentnie poruszał się w tamtym okresie sam Marek Piwowski, śmiało i odkrywczo rozszerzając formułę drapieżnie opisującego peerelowską rzeczywistość kina dokumentalnego. Droga ta biegnie od: studenckich etiud Przedział na sto i więcej osób (1966), Uwertura i Muchotłuk, poprzez Pożar! Pożar! Coś nareszcie dzieje się, aż do bezpośrednio poprzedzających Rejs - Sukcesu i Psychodramy [1].

Maciej Łuczak zauważa, że Muchotłuk (1966), bodaj najbardziej znany szkolny film Piwowskiego, to artystyczna uwertura do Rejsu, w Uwerturze (1965) zaś odnajduje dialogi godne fabularnego debiutu reżysera[2].

By mechanizmy stylizacyjne we wczesnych utworach Marka Piwowskiego stały się czytelne, konieczne jest przywołanie kilku istotnych ustaleń literaturo- i filmoznawców na temat parodii. Janusz Sławiński uważa, iż zabieg ten „polega na podjęciu jakiegoś dającego się rozpoznać sposobu mówienia, który zostaje odcięty od swoich zwykłych uzasadnień (sytuacyjnych lub treściowych) i wprowadzony w kontekst przeczący jego charakterowi, dzięki czemu ulega komicznemu

[1] M. Hendrykowski, Rejs, „Klasyka Kina”, Wydawnictwo Naukowe UAM, Poznań 2005, s. 44 i 49.
[2] M. Łuczak, Rejs, czyli szczególnie nie chodzę na filmy polskie, Prószyński i S-ka, Warszawa 2002, s. 14 i 15. 
wyjaskrawieniu"[3]. Uznaje parodię - rozumianą jako grę ze zużytymi formami literackimi - za główny czynnik motoryczny w procesie historycznoliterackim. „W XX-wiecznej świadomości estetycznej parodia jest traktowana jako jedna $\mathrm{z}$ najbardziej podstawowych i uniwersalnych kategorii twórczości artystycznej”[4]. Zbliżoną definicję parodii odnajdujemy w pracy Henryka Markiewicza, która notabene powstała w czasach, gdy Piwowski realizował swe szkolne filmy:

Parodia sensu largo: komiczne naśladowanie lub przeróbka wzorca literackiego przy pomocy dowolnych środków. Wzorcem może być zarówno konkretny utwór jako zespół cech charakterystycznych twórczości określonego pisarza czy poetyka gatunku literackiego. Parodia sensu stricto: komiczne wyjaskrawienie i zgęszczenie cech wzorca[5].

Dla rozważań nad etiudami Piwowskiego kluczowe okażą się rozróżnienia wprowadzone niegdyś w obrębie stylizacji o komicznym wydźwięku przez Jerzego Ziomka. W artykule Parodia jako problem retoryki pisał, że parodia „znaczy tyle, co «przeciwśpiew», naśladowanie określonego wzorca gatunkowego lub indywidualnego, naśladowanie zazwyczaj przekorne i przez to obniżające wzorca tego godność"[6]. Ziomek podkreślał istotną różnicę pomiędzy parodią a trawestacją. Odwołując się do ustaleń strukturalistów, wskazywał na specyficzną relację pomiędzy planem wyrażania a planem treści. O ile bowiem w zwyczajnych relacjach literackich zamyka się ona w układzie: utwór literacki-rzeczywistość, o tyle w parodii przebiega na linii tekst literacki-inny tekst literacki, w przypadku trawestacji zaś utwór zakorzeniony jest w rzeczywistości pozatekstowej, która staje się przedmiotem żartu[7]. Zdaniem Ryszarda Nycza, w dwudziestowiecznej świadomości estetycznej parodia przestała być wyłącznie formą stylizacji, uzyskała status kategorii estetycznej[8]. Określa ona ogólną zasadę organizacji estetycznej tekstu, polegającą na krytycznej rearanżacji i rekontekstualizacji rozmaitych (w tym sprzecznych) wzorców wypowiedzeniowych[9], a zatem przekazów o nie tylko literackim charakterze:

Szczególnie znamienną cechą współczesnych form parodystycznych jest zainteresowanie dominującymi socjolektami społecznymi, politycznymi, zawodowymi i środowiskowymi [...], których dotycząca immanentna krytyka języka i stylu prowadzi do demaskacji i krytycznej oceny związanych z nimi typów mentalności, wzorców kulturowych i postaw światopoglądowych[10].

[3] J. Sławiński, Parodia, w: Słownik terminów literackich, red. J. Sławiński, Ossolineum, Wrocław 1998,

s. $374^{-375}$.

[4] Ibidem, s. 375.

[5] H. Markiewicz, Parodia a inne gatunki literackie, w: idem, Nowe przekroje i zbliżenia. Rozprawy i szkice $z$ wiedzy o literaturze, PIW, Warszawa 1974, s. 116.

Pierwodruk artykułu ukazał się na łamach „Dialogu” 1967, nr 11.
[6] J. Ziomek, Parodia jako problem retoryki, w: idem, Powinowactwa literatury. Studia $i$ szkice, PWN, Warszawa 1980, s. 362.

[7] Ibidem, s. 368.

[8] R. Nycz, Tekstowy świat. Poststrukturalizm a wiedza o literaturze, Universitas, Kraków 200o, s. 208.

[9] Ibidem, s. 209.

[10] Ibidem, s. 216. 
Typ stylizacji (niezależnie od tego, czy nazwiemy ją trawestacją, czy pewną odmianą parodii), której satyryczne ostrze wymierzone jest w społeczno-polityczną rzeczywistość, określa niemal całą twórczość Piwowskiego.

Filmoznawstwo przejęło właściwie literaturoznawcze definicje parodii. W Słowniku terminów filmowych czytamy, że „parodia jest jedną z podstawowych kategorii świadomości estetycznej kina”, „najbardziej wyrazistą odmianą stylizacji filmowej”. Marek Hendrykowski podkreśla, że toruje ona „drogę nowym oryginalnym zjawiskom w dziedzinie twórczości filmowej”. „Mechanizm parodii polega na ponownym podjęciu cudzego dającego się rozpoznać, charakterystycznego sposobu przedstawiania, odrzuceniu dotychczasowego i wprowadzeniu w nowy ośmieszający kontekst”. Parodia nabiera cech satyry uderzającej w konwencje i wpisane w nie ideowo-artystyczne wizje świata[11]. Niektórzy badacze wiążą parodię, co szczególnie istotne dla naszych dalszych rozważań, z określonymi gatunkami i formami ponadgatunkowymi realizowanymi w kinie. Wśród tych drugich znajduje się mock-dokument. Jane Roscoe i Craig Hight uznają parodię za pierwszy stopień dokumentu fałszywego, wyróżniając w jego obrębie: utwory nostalgiczne (np. Zelig Woody'ego Allena, 1983), mock-dockumentaries (np. This is Spinal Tape Roba Reinera, 1984), mock-soap documentaries (np. Waiting for Guffman, 1996)[12]. Autorzy pracy poświęconej dokumentowi fałszywemu uważają za parodię utwory filmowe, które „[...] wykazują się specyficznym użyciem estetyki przekazów faktualnych i zmuszają odbiorcę do szczególnego rodzaju lektury. Czynią oczywistą ich fikcjonalność, wykorzystując dokumentalne kody i konwencje w celu sparodiowania pewnych aspektów kultury popularnej" [13]. Powiązanie form parodystycznych z dokumentem fałszywym wydaje się ciekawym kontekstem interpretacyjnym dla twórczości Piwowskiego, w której granica pomiędzy przekazem fikcjonalnym a dokumentalnym jest od pierwszych utworów konsekwentnie zacierana.

Spośród czterech etiud zrealizowanych w łódzkiej Szkole Filmowej - Uwertura (1965), Przedział na sto i więcej osób (1965), Muchotłuk (1966) i Kirk Douglas (1966) - tylko jedna nie budzi wątpliwości natury genologicznej. Piwowski korzysta w niej ze stylizacji parodystycznej w najwęższym, najbardziej tradycyjnym rozumieniu terminu. W Przedziale na sto i więcej osób odwołuje się do konwencji thrillera. Opowiada o mężczyźnie samotnie podróżującym pociągiem. Jego wygląd, strój i zachowanie budzą niepokój. Wysoki, szczupły pasażer siedzi w przedziale w płaszczu, skórzanych rękawiczkach i przeciwsłonecznych okularach. Nagle dostrzega leżący na siedzeniu kaszkiet i wyrzuca go przez okno. Po chwili do przedziału wchodzi mężczyzna, zdejmuje kapelusz i zaczyna czytać gazetę. Zwraca uwagę na opatrzone zdjęciem ogłoszenie o nagrodzie wyznaczonej za wskazanie groźnego przestępcy.

[11] M. Hendrykowski, Parodia, w: idem, Słownik terminów filmowych, Ars Nova, Poznań 1994, s. 216. [12] J. Roscoe, C. Hight, Faking it. Mock-documentary and the subversion of factuality, Manchester University Press, 2001, s. 100 i n.

[13] Ibidem, s. 100. 
Człowiek siedzący naprzeciw wygląda identycznie jak ten $\mathrm{z}$ fotografii. Nowy pasażer staje się coraz bardziej nerwowy. Gdy podejrzany zakłada rękawiczki, bohater gwałtownie wstaje i usiłuje wydostać się z przedziału. Morderca blokuje drzwi. Zapada ciemność. Po chwili kamera powraca do jasnego przedziału, w którym pozostał już tylko kapelusz ofiary. Morderca wyrzuca przez okno kolejne nakrycie głowy. Tymczasem do przedziału wchodzi następny człowiek.

Od pierwszych ujęć tego krótkiego filmu Piwowski podejmuje grę z widzem. Wykorzystuje rekwizyty, które charakteryzują bohatera, a jednocześnie funkcjonują jako swego rodzaju klisze. Choć nie pokazuje narzędzi zbrodni, ciemne okulary, długi płaszcz, a przede wszystkim skórzane rękawiczki pozwalają widzowi na natychmiastową identyfikację postaci. Dzięki tym rekwizytom Piwowski może wprowadzić widza od razu w środek akcji, która nie wymaga dodatkowych wyjaśnień. To rekwizyt umożliwia również wyraźne zaakcentowanie punktu zwrotnego w dramaturgii - moment, w którym kolejny pasażer identyfikuje mordercę. Napięcie budowane jest dodatkowo dzięki wykorzystaniu przestrzeni pozakadrowej i elipsy. Zbrodnia nie zostaje ukazana, a jednak widz - doskonale obeznany z eliptyczną naturą kina - wie, że wyrzucenie nakrycia głowy jest pozbyciem się ostatnich dowodów zbrodni. W tym krótkim filmie odbiorca otrzymuje kilka czytelnych, nazbyt oczywistych sygnałów wykorzystania stylizacji komicznej. W sposób groteskowy przerysowana zostaje postać mordercy. Efekt ten potęgowany jest za sprawą specyficznego użycia dźwięku. Nie pada w nim ani jedno słowo. Jazzowa muzyka z motywem trąbki buduje nastrój pierwszej części filmu. To szybka i szalona podróż. W części drugiej milknie trąbka, a jej miejsce w ścieżce dźwiękowej zajmują instrumenty perkusyjne. Na koniec znów powraca trąbka, a pociąg wjeżdża w ciemny tunel, co nie wróży dobrze ostatniemu współpasażerowi mordercy. Klamrowa kompozycja ścieżki dźwiękowej sugeruje, że szaleństwo trwa, a morderca dokonywał zbrodni w przeszłości i będzie robił to nadal. W sposobie organizacji warstwy muzycznej filmu Piwowski odwołuje się do konwencji kina niemego. Jak w kinie, w którym ściśle przestrzegano zasad kodeksu Haysa, zbrodnia dokonana zostaje poza kadrem i pozostawiona domysłom widza. Również w tym elemencie intertekstualnej gry z łatwością daje się wychwycić groteskowe przerysowanie. Trzeci sygnał parodystycznej stylizacji reżyser umieścił w ramie filmu. Jest nim tytuł, który - czytany ex post - po zaprezentowaniu zdarzeń nabiera nowych znaczeń i staje się źródłem makabrycznego, czarnego humoru. W Przedziale na sto i więcej osób Piwowski nie odsyła widza do rzeczywistości pozafilmowej, jak będzie to robił w swych późniejszych filmach, lecz do pewnego repertuaru ogranych chwytów filmowych rodem z kina gatunków i zamierzchłej przeszłości widowisk kinematograficznych. Przedział... nie ma więc charakteru satyry, a jedynie zabawy konwencjami, żartu filmowego.

Nakręcona rok później etiuda Kirk Douglas stanowi nieco inny przypadek wykorzystania stylizacji parodystycznej. Tym razem 
mamy do czynienia z filmem, który najczęściej kwalifikowany bywa jako reportaż z wizyty słynnego hollywoodzkiego aktora w łódzkiej Szkole Filmowej, ale jest przecież jednocześnie czymś więcej. Twórcy etiudy - Piwowski i Feridun Erol - odwołują się w niej nie tylko do rozwiązań typowych dla przekazów niefikcjonalnych, lecz także do chwytów charakterystycznych dla jednego z najbardziej skonwencjonalizowanych gatunków w historii kina - westernu. I znów, jak w Przedziale..., najistotniejszym sygnałem nawiązań stylistycznych są rekwizyty i elementy scenografii: kolty, kapelusze, konie, fasada saloonu. Pierwsza oznaka komicznej stylizacji znów pojawia się w ramie filmu. Otwiera go ujęcie ukazujące wymalowany na łysej głowie studenta-aktora napis: „Polish Film School PWSFiT presents”. W kolejnym widzimy wypisane na planszy charakterystyczną „westernową" czcionką słowa powitania: „Welcom Kirk”. Spod napisu wyłania się grupa studentów-aktorów przebranych za kowbojów. Kolejne ujęcie filmu utrzymane jest już w stylistyce typowej dla form niefikcjonalnych, reportażowych. Szeroki plan pozwala zorientować się w sytuacji. Kamera rejestruje wjazd limuzyny na teren uczelni i filmuje drugą ustawioną na szynach kamerę - odsłaniając po raz pierwszy - ale nie ostatni - akt filmowania. W wielu ujęciach tej etiudy eksponowane są liczne kamery, sprzęt do nagrywania dźwięku, szyny i wózki. Piwowski i Erol nieustannie zaznaczają sztuczność wykreowanej rzeczywistości westernowej i przenoszą ją za pomocą dźwięku na reportażowe elementy filmu. Choć bohater wydarzenia przyjeżdża samochodem, to w tle słyszymy tętent koni. Gdy aktor zaangażuje się w swego rodzaju performance [14], jaki zaproponowali studenci, i zacznie pokazywać im markowanie ciosów, usłyszymy dźwięki uderzeń. Ścieżkę dźwiękową niemal bez reszty wypełnia muzyka rodem $\mathrm{z}$ westernów, która raz staje się elementem dominującym, by za chwilę wybrzmiewać tylko $\mathrm{w}$ tle zarejestrowanych rozmów, spontanicznych reakcji. Gra pomiędzy kreacją a rejestracją, zmyśleniem a dokumentem, zacieranie granicy pomiędzy dwoma podstawowymi rodzajami filmowymi wydaje się istotą tej etiudy. Stopniowo jednak, po scenach typowych dla reportażu, jak rejestracja spotkania w sali kinowej i rozmowy ze studentami, żywioł inscenizacji i kreacji zaczyna dominować nad pierwiastkiem niefikcjonalnym. W kadrze pojawia się plansza ze zdjęciem aktora i napisem: „Wanted Kirk Douglas. Reward: 1.00o.ooo\$”. Douglas wsiada na konia. Studenci-aktorzy i sława światowego kina odgrywają scenę bójki pod saloonem. Ktoś spontanicznie wskakuje na konia, a Douglas próbuje go zrzucić. W scenie strzelaniny użyto dźwiękowego efektu imitującego strzał, rozbrzmiewają fragmenty westernowych dialogów. Z walki aktor

[14] Wizyta Douglasa nie była przygotowywana miesiącami. Jerzy Bossak, ówczesny dziekan Wydziału Reżyserii, dzień przed przybyciem gościa odebrał telefon $\mathrm{z}$ informacją o jego przyjeździe. Zadanie zrealizowania filmu na ten temat zlecił studentowi III roku reżyserii Markowi Piwowskiemu, który wraz z kolegą z roku Feridunem Erolem, przygotowującym $\mathrm{w}$ tym czasie musical westernowy dla łódzkiego teatru „7.15”, w ciągu jednej nocy przenieśli na teren uczelni scenografię miasteczka z Dzikiego Zachodu, kostiumy i rekwizyty. 
wychodzi zwycięsko i gdy w ostatnich ujęciach dziewczęta wręczają mu kwiatki, to jest to hołd dla zwycięzcy i aktora jednocześnie.

Inaczej jednak niż w Przedziale..., w quasi-reportażu Piwowskiego i Erola parodystyczne zabiegi mają wyraźne odniesienie do konkretnej rzeczywistości społeczno-politycznej. Po niemal dwudziestu latach, gdy w Polsce trwał już stan wojenny, Kirk Douglas wspomniał:

Ludzie byli ubrani jak kowboje, strzelali z pistoletów. Dokoła młodzi ludzie, pełni energii. Aktorzy, muzycy, pisarze, reżyserzy - wszyscy spragnieni wolności. Wydawali się być pełni oddania i radości. Aktor potrafi odróżnić rzeczywistość od fikcji. Szczęśliwe chwile, które razem spędziliśmy, były prawdziwe. Walka była udawana[15].

Parodystyczne odniesienia do westernu pojawiły się więc w filmie Piwowskiego i Erola w dwóch funkcjach. Wykorzystanie tej konwencji w happeningu było szczególną formą uczczenia wyjątkowego gościa, który wielokrotnie wcielał się w role kowbojów i rewolwerowców, choćby w Ostatnim kowboju (1962) Davida Millera czy Pojedynku rewolwerowców (1971) Lamonta Johnsona. Było jednak przede wszystkim wyrazem tęsknoty za wolnością, możliwością wyboru jako konstytutywnymi cechami kultury Zachodu, której uosobieniem jest niezależny, wolny bohater westernu. Jedna z kilku definicji parodii, jaką podaje Ryszard Nycz, brzmi: „W odniesieniu do poszczególnych utworów literackich określa ona ogólną zasadę organizacji artystycznej, polegającą na krytycznej rearanżacji i rekontekstualizacji rozmaitych (w tym sprzecznych) wzorców wypowiedzeniowych" [16]. Istotny punkt odniesienia dla zabiegów parodystycznych w etiudzie ma charakter wewnątrztekstowy. Sygnałem jego istnienia są ujęcia reportażowe w filmie, których stylistyka stoi w pewnej sprzeczności ze stylizacją westernową. Celowo jest w nich podkreślana obecność kamery i inscenizacji. Świat przed kamerą stworzony na potrzeby reportażu i inscenizacja na potrzeby happeningu należą do tego samego, „sztucznego” porządku. Rzeczywistość PRL połowy lat 6o. poza murami przy ulicy Targowej była dużo bardziej zgrzebna i odpychająca.

Owa specyficzna gra elementami fikcjonalnymi i niefikcjonalnymi widoczna jest już w pierwszej etiudzie Piwowskiego, która klasyfikowana jest zwykle jako dokument. Uwertura, podobnie jak fabularny Przedział..., powstała w roku 1965, podczas drugiego roku studiów reżysera. Pierwotnie zatytułował on film Poborowi. Zmiana tytułu jest $\mathrm{w}$ tym przypadku istotną sugestią interpretacyjną dla odbiorcy. Tadeusz Lubelski zauważa: „Tytuł Uwertura wydobywa kontrast między bezduszną rutyną instytucji a autentyzmem wchodzących w życie młodych ludzi" [17]. Piwowski opowiada o młodych mężczyznach stających przed komisją wojskową. Rzecz rozgrywa się w dwóch pomieszczeniach:

[15] Cytat pochodzi za ścieżki dźwiękowej amerykańskiego programu telewizyjnego Let Poland be Poland (1982).

[16] R. Nycz, op. cit., s. 209.
[17] T. Lubelski, Polska Szkoła Dokumentu. Marek Piwowski, Polskie Wydawnictwo Audiowizualne, Warszawa 2008, brak numeracji stron. 
w jednym młodzieńcy stają przed komisją lekarską, w drugim - przed poborową. Każdy poborowy trafia najpierw do gabinetu lekarskiego, gdzie musi się rozebrać, jest bacznie oglądany, mierzony i ważony. Ciało, cechy budowy stają się tu często przedmiotem niewybrednych żartów i kpin personelu. Jedna z lekarek komentuje głośno zza parawanu owłosienie łonowe badanego mężczyzny: „To trwała ondulacja, czy to tak natura obdarzyła pana? Zupełnie jak z Afryki”. „Gdyby ciocia miała wąsy to byłby wujek" - zwraca się do współpracowników. Na co jeden z lekarzy odpowiada: „Gdyby ciocia miała patafiana, to by było dziecko”. Piwowski nie ośmiesza jednak poborowych, jak robią to lekarze, lecz wydobywa absurdalność sytuacji. Ukazuje mężczyzn w samej bieliźnie, stających przed umundurowanymi członkami komisji i lekarzami w fartuchach. Poborowi wydają się skrępowni, nie wiedzą, jak powinni się zachować. Kamera chwyta więc w bliskich planach ich miny, szeroko otwarte usta, nagie stopy, wyszczerzone zęby, wystawione języki.

Przedmiotem parodii $\mathrm{w}$ Uwerturze $\mathrm{z}$ pewnością nie jest forma dokumentalna. Jest ona raczej narzędziem służącym parodiowaniu pozaliterackich form wypowiedzi. Narastanie tendencji do czynienia przedmiotem parodii języka publicznego badacze zauważają w literaturze lat 6o., gdy wzrasta znaczenie parodii w sztuce w ogóle:

Od lat 60. parodystyczna poetyka zyskuje stopniowo coraz większe znaczenie i popularność, stymulowana w istotnej mierze atrakcyjnością Gombrowiczowskiej formuły parodiopisarstwa, jak też ogólnymi tendencjami geograficzno-kulturowymi (Kapuściński, Mieszalski, Musiał, Pankowski, Pilch, Skrzyposzek). [...] Bywa dialogiem z tradycją literacką (Kuśniewicz, Międzyrzecki, Parnicki). I wreszcie, co nie najmniej ważne, wewnętrzną krytyką publicznego języka - zwłaszcza w jego ważnych społecznie odmianach funkcjonalnych „języka gazet” $i$,języka władzy” - krytyką sięgającą w konsekwencji jego podstaw i uprawomocnień: społecznych, kulturowych, epistemologicznych i ideologicznych[18].

Główne narzędzia parodystycznych zabiegów w warstwie słownej filmu Piwowskiego to hiperbolizacja i powtórzenie. Film otwiera ujęcie sali, w której zgromadzeni zostali poborowi. Ze sceny przemawia do nich członek komisji:

Poborowi! Witam was serdecznie na komisji poborowej. Zadaniem komisji poborowej będzie orzec o stanie waszego zdrowia, czy nie kontynuujecie nauki, studii. I wtedy przyjdzie taki dzień w waszym życiu, kiedy staniecie przed bramami koszar naszych. Jest prośba do was taka, ażeby w lutym stawić się w jednostce w stanie trzeźwym.

Wielokrotnie słyszymy rutynową wypowiedź lekarki wypełniającej kartę chorobową. Kobieta wylicza wiele chorób, których poborowy nie przechodził: „Operacji nie było, złamań nie było, z uszu nie wyciekało, serce nie boli, żołądek nie boli, gruźlicy nie było, cukrzycy nie było, żółtaczki nie było, a może padaczka była... Następny stoi rozebrany”. Personel, niezadowolony z nadmiaru pracy, przedmiotowo traktuje badanych.

[18] R. Nycz, op. cit., s. 215. 
Właściwie nie wchodzi z nimi w dialog. Wywiad z pacjentem to czysta rutyna. Bez zażenowania kobiecy głos mówi o mężczyznach „pacany”. Słychać narzekania, że włażą, że mnożą się nie wiadomo dlaczego. O poborowych mówi się zwykle w trzeciej osobie w ich obecności. Gdy zaś personel zwraca się do nich, używa zgodnej z partyjną nowomową drugiej osoby liczby mnogiej. Słowa i gesty depersonalizują pacjentów. Krytyczny ton Uwertury wzmocniony zostaje przez jej komizm, którego źródłem są nie tylko słowa, ale ich specyficzne zestawienie z obrazem. Niemal wszystkie wypowiedzi lekarzy słyszymy wyłącznie z offu. Zmontowane zostały z galerią twarzy i ciał kolejnych badanych. Lekarze chwytają ich za policzki, obracają, zaglądają do ust i uszu. W tej części Uwertury poborowi milczą. Piwowski filmuje ich zakłopotanych, zamyślonych. Młodzieńcy nie rozumieją poleceń lekarzy, nie pojmują sytuacji, w której się znaleźli, i roli, jaką mają w niej odegrać. W części drugiej jeden $z$ nich dopuszczony zostaje do głosu, ale jego słowa zdają się nie mieć żadnego znaczenia. Przewodniczący komisji zwraca się do niego: „Żeby zachować zasadom demokracji, ja się was pytam, gdzie chcielibyście służyć. I teraz możecie to moje pytanie podchwycić i powiedzieć: ja chciałbym służyć w wojskach powietrzno-desantowych i wtedy ja wam powiem: zgoda”. Mimo że młodzieniec ma lęk wysokości i tak trafia do wojsk lotniczych. „No, więc z tego mojego wysondowania nic nie wyszło..." - podsumowuje sytuację szef komisji. W finale filmu bliskie plany twarzy poborowych - robiących miny na polecenie lekarzy lub zamyślonych, jakby nieobecnych - zmontowane zostały na przemian. W warstwie dźwięku towarzyszy im głos lekarki wymieniającej schorzenia i powtarzana wypowiedź przewodniczącego o zachowaniu zasad demokracji. Młodzi ludzie, wchodzący dopiero w dorosłość, wpadają w tryby zbiurokratyzowanej, państwowej machiny. Sytuacja przed komisją to zaledwie uwertura do przyszłego życia, zapowiedź zniewolenia, które stanie się udziałem bohaterów. Piwowski ukazuje w parodystycznej formule podstawową zasadę funkcjonowania totalitarnego systemu, podkreślając jednocześnie brzydotę, odrażające oblicze jego funkcjonariuszy. Używa w tym celu gwałtownych najazdów kamery, eksponujących na przykład szyderczy uśmiech lekarza. W warstwie słownej wydobywa wulgarność mowy, błędy językowe, bylejakość, która koresponduje z przaśną rzeczywistością PRL - systemu, w którym demokracja to tylko fasada. Opisując zjawisko nowomowy, Michał Głowiński zauważał:

Parodia uczy nieufności i podejrzliwości wobec nowomowy, ujawnia jej mechanizmy, wskazuje na nadużycia. Charakteryzuje ona nie tylko twórczość o ambicjach najwyższych, dochodzi do głosu - przynajmniej niekiedy - w kulturze masowej, a także - w mowie potocznej. Parodia działa jak antytoksyna. Nowomowa - niechcący oczywiście - w jakiejś mierze jej sprzyja. Tym bardziej że i w niej samej występują elementy parodii niezamierzonej. Pewnego typu wypowiedzi są chyba dość powszechnie odbierane jako parodystyczne, choć nie takie były intencje ich autorów [19].

[19] M. Głowiński, Nowomowa po polsku, Pen, War-

szawa 1990, s. 22-23. 
W kontekście tych uwag wypowiedź lekarki i pytania przewodniczącego nabierają nowych znaczeń. Punktem odniesienia dla parodystycznej formuły pierwszego szkolnego filmu Marka Piwowskiego jest konkretna zaobserwowana rzeczywistość i obowiązujący w niej język. Reżyser wspominał: „W Uwerturze przeciwstawiam obraz (to, co się dzieje naprawdę) warstwie dźwiękowej - nowomowie, którą posługuje się komisja poborowa, wyrokując o losie "podsądnego». To konsekwentny podział" [20]. W ostatnim zrealizowanym w szkole filmie - Muchotłukuujawnia Piwowski skłonność do parodiowania zarówno zastanych form języka, jak i klisz kulturowych oraz konkretnych utworów filmowych. Etiuda ta zapowiada najbardziej charakterystyczne cechy stylu reżysera, jednego z najkonsekwentniejszych twórców w historii polskiego kina.

W Muchotłuku bez trudu odnajdujemy nawiązania do prozy Tadeusza Konwickiego, do scen z Popiołu i diamentu, do mitów narodowych i wzorów kulturowych. Etiudę rozpoczyna ujęcie ukazujące perkusistę, który przygotowuje się do występu. Już po chwili rozbrzmiewa melodia pieśni Czerwone maki, miesza się z gwarem. Warto w tym miejscu przypomnieć, że pieśń upamiętniająca zdobywców Monte Cassino rozbrzmiewała w tle sceny z płonącym spirytusem w Popiele i diamencie (1958). Dla pokoleń Polaków scena ta stała się wyrazem swego rodzaju myślenia patriotycznego, które swymi korzeniami sięgało romantycznych tradycji przefiltrowanych przez międzywojenną edukację. Polemiczny wobec niej stosunek widoczny był już w zrealizowanym kilka lat później filmie Wojciecha Jerzego Hasa Jak być kochana (1963), gdzie utożsamiany z Chełmickim Cybulski gra rolę mitomana, pijanego kabotyna, żyjącego wyssanymi z palca wojennymi legendami. W „knajpianej scenie” tego filmu Czerwone maki grane są na fałszywą nutę przez „bajzelmamę” i śpiewane przez podpite towarzystwo. W Muchotłuku pieśń ta oraz rozbrzmiewający w finale Mazurek Dąbrowskiego stanowią znaczeniową klamrę. Piwowski ukazuje skarlenie, odsłania odpychającą gębę polskiego społeczeństwa połowy lat 6o. Tropów tego rodzaju jest w Muchotłuku znacznie więcej. Przykładem parodystycznego odwołania do zakorzenionych $\mathrm{w}$ naszej kulturze symboli, tym razem o proweniencji stricte literackiej, jest scena "chocholego tańca”. Notabene ten sam trop kulturowy wykorzystany został w finałowych ujęciach przywoływanego już Popiołu $i$ diamentu czy w jeszcze innej funkcji w Salcie (1964) Tadeusza Konwickiego. O ile jednak Wajda i Konwicki odwołali się w swej wizji społeczeństwa pogrążonego w stuporze do konwencji surrealizmu, o tyle Piwowski sięgnął po ujęcie parodystyczno-groteskowe. Zgromadzeni w podrzędnej knajpie bohaterowie etiudy nagle podrywają się z miejsc i zaczynają zapamiętale tańczyć w rytm kankana wygrywanego przez nieznośnie rzępolących grajków. Na parkiet wychodzą wszyscy: młodzi i starzy, mężczyźni i kobiety, panowie proszą panów. Relacje pomiędzy tancerzami oraz przyjmowane przez nich pozy stają się karykaturą narodowej jedności.

[2o] M. Łuczak, op. cit., s. 14 . 
Film Piwowskiego oddaje ówczesny stan polskiej duszy, o którym wiele mówił tytuł etiudy. Jego autorem był opozycyjny satyryk Janusz Szpotański. Oznacza on „taniec małp w społecznej próżni - pudle, które nie wydaje rezonansu" [21].

W podrzędnej knajpie, która jest jedyną przestrzenią zdarzeń w etiudzie, zebrali się przedstawiciele kilku pokoleń, rozmaitych środowisk, osoby o różnym statusie społecznym i materialnym. Jest wśród nich defilujący w takt Czerwonych maków podpity weteran ostatniej wojny, który z nienawiścią spogląda na gościa bliźniaczo podobnego do Adolfa Hitlera. Krępy mężczyzna w średnim wieku składa niemoralne propozycje przysadzistej kelnerce. Starszy wychudzony człowiek narzeka na warunki zatrudnienia i żąda „etatu na konia”. Zdegenerowany starzec nie jest nawet w stanie nawiązać z nim dialogu. Paserzy handlują zegarkami, ktoś opowiada niewybredne dowcipy („Spotkał się Amerykan, Ruski i Szkop...”), ktoś inny gra na flecie. Wszyscy piją wódkę lub tanie wino, jedzą kiełbasę i zagryzają ją suchym chlebem. Atmosfera przaśnej zabawy gęstnieje, gdy do sali wchodzą milicjanci. Śmiech milknie, jeden z gości pośpiesznie udaje się do toalety, kierownik lokalu wskazuje kogoś palcem. Młody mężczyzna szybko wypija kieliszek wódki i wychodzi, zakładając kask motocyklowy. Po chwili do knajpy dociera dźwięk hamulców i uderzenia. Około północy, gdy z radiowych głośników rozlega się hymn, nadawany na zakończenie programu, większość klientów przysypia na stołach lub w pijackiej drzemce osuwa się z krzeseł. I nawet stanowczy apel weterana ostatniej wojny o powstanie „Za braci poległych, ze krew przelaną” spotyka się z całkowitą obojętnością. W ujęciu finałowym milicjanci wyprowadzają powłóczącego nogami kloszarda.

Piwowski, który niebawem stanie się jednym z ważniejszych twórców w obrębie „szkoły krakowskiej”, już w tym filmie posługuje się dominującą w polskim dokumencie lat 70. metodą, którą lapidarnie opisał w jednym z wywiadów Marcel Łoziński:

Było wiadomo, że kiedy Kieślowski kręcił Fabrykę, nie miał to być tylko film o trudnej sytuacji Ursusa, a kiedy Zygadło w Szkole podstawowej pokazywał donosicielstwo i łamanie charakterów w jakiejś konkretnej szkole, miał na myśli nie tylko szkołę. Wszystkie te filmy dotyczyły czegoś, co dziś nazywasz systemem. Były rodzajem metafory, pars pro toto[22].

Figurę tę stosował Piwowski, uzupełniając ją o własny rys: hiperbolę, parodystyczną stylizację i kategorię groteski. Stworzył więc groteskowo zdeformowany obraz polskiego społeczeństwa pogrążonego w pijaństwie i marazmie, niezdolnego do jakiegokolwiek działania, mitomańskiego. W sposób satyrycznie przerysowany przedstawił wycinek polskiej obyczajowości i języka doby „małej stabilizacji”.

Tadeusz Lubelski w omówieniu Muchotłuka wspomina:

[21] Ibidem, s. 15.

[22] M. Łoziński, Trzeba odnaleźć ten jeden delikatny ton, [rozmawiał] Tadeusz Sobolewski, „Kino” 1992, nr 8. 
Reżyser zebrał około dwustuosobowe grono łódzkich naturszczyków, jak określiła to jedna z jego koleżanek, „zbieraninę alkoholików i wykolejeńców z Fabrycznej i Abramowskiego, same słynne postacie z półświatka", uzupełnione o Irenę Iżykowską i Wacława Antczaka - parę „artystów $\mathrm{z}$ zamiłowania", często przesiadujących $\mathrm{w}$ szkole filmowej z nadzieją na statystowanie, po czym umieścił ich wszystkich w szkolnym atelier przerobionym na podrzędną knajpę i stworzył film z obserwacji ich zachowań[23].

Film nie składa się jednak wyłącznie z rejestracji przebiegu zdarzeń. Obserwacja walczy w nim z żywiołem inscenizacji, dzięki której Piwowski próbuje zrekonstruować zasłyszane niegdyś dialogi, podpatrzone sytuacje. Spontanicznych reakcji bohaterów nie sposób właściwie odróżnić od rozmów improwizowanych i inspirowanych przez twórcę. Piwowski zmontował etiudę, rozcinając i przeplatając sceny, które rozgrywały się $\mathrm{w}$ różnych miejscach knajpy. Kamera zawsze trafia jednak na momenty kluczowe w ich mikrodramaturgii, na najbardziej komiczne fragmenty dialogów gdy, na przykład, z ust Iżykowskiej padają pamiętne zdania: "Przerwa w piciu grozi życiu”, „Za stówę? Kup pan sobie herbatników” czy „Ale ja z panem nie mogę, bo pan mnie rozśmiesza”.

Muchotłuk jest spośród szkolnych filmów Piwowskiego najpełniejszą zapowiedzią ponadgatunkowej, parodystycznej formuły mock-dokumentu, po którą twórca będzie sięgał wielokrotnie, choćby w debiutanckim Rejsie (1970) czy w telewizyjnym Kroku (1997). Przystępując do zdjęć do Muchotłuka, zgromadził naturszczyków w szkolnym atelier, w którym zaaranżował typowy, przaśny peerelowski lokal. Niektóre ujęcia zrealizował kamerą obserwacyjną. Rejestrował dialogi i zachowania swych bohaterów. Część scen to konsekwencja inscenizacji, często opartej na rekonstrukcji zaobserwowanych wcześniej sytuacji. Nagromadzenie, spiętrzenie tragikomicznych dialogów i charakterystycznych postaci-typów prowadzi do stworzenia świata na opak, w którym rządzi absurd i groteska. Otrzymujemy wizję rzeczywistości karykaturalnie zdeformowanej, w której błazenadzie towarzyszy rozpacz, w której lekceważone jest decorum [24]. Michał Głowiński, a za nim Ryszard Nycz, omawiając prozę Witkacego, uznają parodię za „dominującą technikę artystyczną w służbie groteski jako globalnej i nadrzędnej kategorii estetyczno-światopoglądowej jego twórczości”[25]. Również w twórczości Marka Piwowskiego parodia służy grotesce, lecz sytuację dodatkowo komplikuje rodzajowa hybrydyczność jego utworów. W Muchotłuku sygnały przynależności genologicznej są konsekwentnie zacierane, tak że widz do końca nie ma pewności, czy obcuje z materią fikcjonalną czy dokumentalną. Podobnie skonstruowany został Rejs - film z udziałem licznego grona naturszczyków, w dużej mierze improwizowany, z dość swobodną konstrukcją dramaturgiczną. Za pierwszy mock-dokument w dorobku reżysera uznawana jest zwykle dopiero parodia telewizyj-

[23] T. Lubelski, op. cit., brak numeracji stron.

[24] Por. J. Sławiński, Groteska, w: Słownik terminów literackich, op. cit., s. 188.
[25] R. Nycz, op. cit., s. 213. Por. M. Głowiński, Parodia konstruktywna, w: idem, Gry powieściowe. Szkice $z$ teorii i historii form narracyjnych, PWN, Warszawa 1973, s. 282. 
nych form faktualnych (reportażu, rekonstrukcji dokumentalnej w stylistyce programu telewizyjnego 997) Egzekucja długów, ludzi (2001). Za łże-dokument uważa go Wiesław Godzic[26]. Beata Kosińska-Krippner wymienia go obok filmu Krzysztofa Gradowskiego Déjà vu, czyli skąd my to znamy z roku 1977. W rolę dziennikarza-śledczego wciela się w nim reżyser. Od pierwszych scen otrzymujemy więc wyraźny sygnał „fałszywości” przedstawionych zdarzeń. Piwowski dość konsekwentnie odwołuje się jednak do konwencji telewizyjnych, długo podtrzymując niepewność widza co do rodzajowej przynależności filmu i statusu ontologicznego ukazanego świata. W miarę postępowania akcji nagromadzenie absurdu staje się jednak tak wyraźne, że charakter komunikatu przestaje budzić wątpliwości. Zbliżoną poetyką charakteryzują się w moim przekonaniu - także wcześniejsze filmy Piwowskiego, które można uznać za pierwsze próby mock-dokumentalne, tym bardziej że większość z nich ma, jak klasyczne mock-dokumenty, charakter parodystyczny[27]. Poza wskazanymi już tytułami warto przywołać: Pożar! Pożar! Coś nareszcie dzieje się (1967), Sukces (1968), Korkociagg (1971), Hair (1971), Krok (1997) i widowisko telewizyjne Nóż w głowie Dino Baggio (1999). W Pożarze... - swojej pierwszej produkcji profesjonalnej - Piwowski łączył dokumentalną obserwację z inscenizacją w patchworkową, groteskową wizję życia niewielkiego miasta Kętrzyn, które Hitler wybrał niegdyś na swą kwaterę główną. Film powstał na zamówienie Wytwórni Filmów Dokumentalnych w ramach międzynarodowego projektu pod hasłem: „Co robi młodzież w twoim kraju w sobotnie popołudnie”. Sukces, Korkociagg i Hair są na pierwszy rzut oka tradycyjnymi dokumentami. Pierwszy z nich to kontrowersyjny portret Czesława Niemena[28]. Przyglądamy się próbom do kolejnego koncertu, mozolnemu powtarzaniu poszczególnych taktów piosenek, a jednocześnie obcesowym zachowaniom gwiazdora, który był wówczas u szczytu popularności. Sceny z sali prób Piwowski połączył z fragmentami wywiadu z Niemenem. Bohater z ironicznym uśmiechem, patrząc w kamerę, opowiada o swoim sukcesie, ale i wypowiada się na tematy obyczajowe. Jego poglądy i zachowanie są rodzajem prowokacji wobec widza, grą z uładzonym, medialnym wizerunkiem gwiazdora, który jako przedstawiciel ruchu kontestacyjnego nie należał do ulubieńców władzy. Hair to z pozoru pozbawiony komentarza reportaż obserwacyjny z IX Konkursu Sztuki Fryzjerskiej Krajów Socjalistycznych o Puchar Przyjaźni. Piwowski nie stara się jednak szukać typowego dla poetyki reportażu neutralnego punktu widzenia. Opowieść konstruuje tak, by wydobyć absurd przedsięwzięcia $\mathrm{z}$ okazji „40 lat współpracy państw socjalistycznych na polu fryzjerstwa”. Umieszcza ujęcia chałturzących muzyków, kiczowatych fryzur i absurdalny komentarz konferansjera.

[26] W. Godzic, Telewizja i jej gatunki po Wielkim Bracie, Universitas, Kraków 2004, s. 193-194. [27] B. Kosińska-Krippner, Parodystyczna natura przywłaszczeń kodów faktualnych i konwencji w mock-dokumentach, „Kwartalnik Filmowy”, nr 54-55, 2006.
[28] Należy jednak pamiętać o kontekście historycznym i ówczesnym bardzo negatywnym przyjęciu filmu. Przez wielu widzów odczytany on został jako paszkwil na Niemena, zgodny z zapatrywaniami władzy na postawę i twórczość muzyka. 
Korkociąg otwierają i zamykają fragmenty zainscenizowanego przemówienia „dla uczczenia 52. rocznicy wielkiej gałęzi przemysłu: przemysłu spirytusowego". Pobrzmiewa w nim, słyszalna również w innych filmach Piwowskiego, skłonność do parodystycznego traktowania partyjnej nowomowy. Zasadniczą część filmu stanowią ujęcia ukazujące kolejne fazy alkoholowego uzależnienia. Zestawienie języka partii z obrazami z oddziału odwykowego wywołuje najpierw śmiech, potem niesmak, w końcu przerażenie. Krok i Nóż w głowie... uważane są zwykle za utwory o charakterze fikcjonalnym. W obu reżyser odwołuje się jednak do konwencji dokumentalnych: reportażu telewizyjnego i relacji na żywo. Tadeusz Lubelski pisze o Kroku:

Film dość długo przestrzega reguł reportażu telewizyjnego, zgodnie z bardzo poważnym punktem wyjścia: agent naszych służb specjalnych, podczas niedawnego pobytu w sztabie NATO w Brukseli, zdobywa wiadomość, że władze paktu oczekują zmiany kroku defiladowego, obowiązującego w polskiej armii. [...] Scena zebrania tej komisji nie pozostawia już wątpliwości, że mamy do czynienia z przebraną za reportaż - komedią. Film jest najbardziej udaną realizacją nowej formuły filmu telewizyjnego, wypracowywanej przez Piwowskiego w latach 90. - na pograniczu happeningu i satyry politycznej[29].

W Nożu w głowie... Piwowski odnosi się do autentycznego wydarzenia, które miało miejsce w roku 1998, gdy podczas meczu piłkarskiego pomiędzy Wisłą Kraków a AC Parma jeden z kibiców trafił nożem włoskiego pomocnika.

W wielu filmach Piwowski powtarza wypracowany już w etiudach szkolnych zabieg kontrastowego zestawiania elementów świata przedstawionego lub stopniowego wypierania jednej konwencji przez drugą. Rozwiązania te wydają się bliskie mock-dokumentowi, w którym widz otrzymuje mniej lub bardziej zawoalowane sygnały statusu ukazywanej rzeczywistości. O jej fikcjonalności przekonuje się zazwyczaj w miarę postępowania akcji. Sięganie po formułę dokumentalną, intertekstualne gry w kinie Piwowskiego nie są tylko czystą zabawą. Filmy te związane są ściśle z konkretną rzeczywistością społeczno-polityczną: Polski Ludowej, Polski po roku 1989 - kraju drapieżnego kapitalizmu i ogromnych aspiracji europejskich. Reżyser wskazuje na rzeczywistość jako główny przedmiot zabiegów parodystycznych. W większości filmów podstawowym schematem, według którego odsłania ich konwencję, jest stopniowe narastanie absurdu, które osuwa przekaz w stronę fikcji. Warto jednak zaznaczyć, że ów absurd ma zawsze źródło w konkretnym „tu i teraz”.

[29] T. Lubelski, op. cit., brak numeracji stron. 


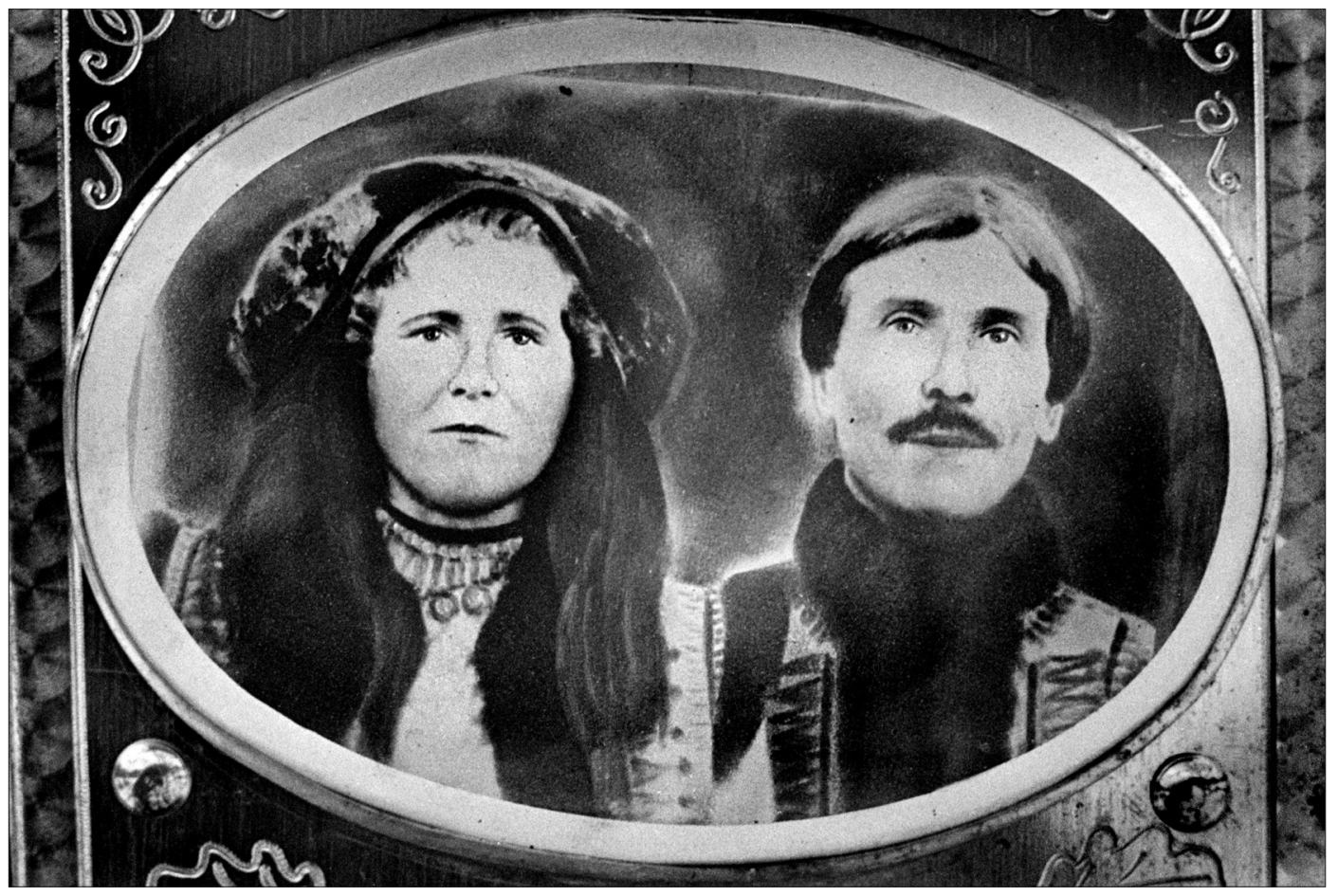

Fot. Maciej Łabudzki 